\title{
Norwidowska koncepcja nadziei
}

Słowa klucze: Norwid, idiolekt, nadzieja, poeta, kapłan

Jadwiga Puzynina (2006: 126, 127, 145) wskazuje, że w dość złożonej Norwidowskiej wizji poezji i poety ,do istoty bycia poetą należy przekazywanie ludziom nadziei”, która z kolei - jej zdaniem - „wiąże się ściśle z walką o prawdę", a nawet jest jej zwycięstwem ${ }^{1}$. Norwid, określając poetów zarówno przedchrześcijańskich, jak i tych, którzy po narodzeniu Chrystusa głoszą nadzieję dla „narodu i narodowości”, kapłanami nadziei, zespala ich posłannictwo z wymiarem eschatologicznym dziejów i jego szczytowym momentem - odkupieńczą ofiarą Chrystusa. W lekcji I O Juliuszu Stowackim czytamy:

Gdzież więc ci kapłanowie nadziei od chwili, w której spełnia się na ołtarzu święta Ofiara [...]. Gdzież więc, mówię, ci kapłanowie odchodzą?! - oto odchodzą oni poza Niedzielę tej nadziei, oto odchodzą w dnie jej powszednie i robocze, albowiem dla człowieka pojedyńczego nadzieja jest już spełniona, ale dla człowieka zbiorowego, narodu i narodowości poczynającej się spełnienia nie było. Tam więc oni odchodzą, a przeto urzędu swego, kapłań st wa nadziei, nie składają, który zaś nie poruszył się z miejsca i przy ołtarzu pozostał, ten

${ }^{1}$ Na związek nadziei i prawdy zwracał uwagę m.in. Józef Tischner (1994: 10), dla którego nadzieja jest „najwłaściwszą dla nas perspektywą odkrywania i oglądania prawdy, prawdy o chrześcijaństwie, o człowieku, o naszym świecie”. 
stawał się świątecznego języka poetą, jak nasz Sarbiewski, gdy tymczasem inni odchodzą witać całość, co jeszcze blasku Zbawicielowego nie doznała. (PW VI 409-410)².

Zarówno Norwidowskie rozumienie poety, jak i kapłana doczekało się już własnych filologicznych opracowań (por. Puzynina 2006, Kadyjewska i in. 2000) ${ }^{3}$, do dziś jednak nie ma żadnego ${ }^{4}$ studium, które przybliżałoby koncepcję nadziei autora Vade-mecum. W tym tekście refleksji poddam takie kwestie, jak: czym jest relacja nadziei i jak jest ona wyrażana w tekstach Norwida, jaka na tle ogólnego znaczenia nadziei jest specyfika nadziei Norwidowskiej i czy można mówić o różnych jej rodzajach, skąd się ona - zdaniem Norwida - bierze, jakie pełni funkcje w budowaniu osobowości człowieka i w jego życiu, jaki jest jej związek z poezją, czy człowiek, a zwłaszcza poeta, jest dawcą czy zwiastunem nadziei, jak na tle własnej koncepcji nadziei Norwid widział swoją twórczość, czy sam siebie uważał za poetę - kapłana dni powszednich nadziei i wreszcie, jak z perspektywy badacza ma się do tej koncepcji nadziei twórczość Norwida, który w wielu tekstach jawi się przecież także jako świadek rozpaczy, czy dałoby się więc określić go mianem kapłana nadziei.

\section{I}

Pojęcie 'nadziei', którego najczęstszym wykładnikiem w języku polskim jest zwrot mieć nadzieję, że_, odnosi się do relacji zachodzącej między jej podmiotem - zazwyczaj człowiekiem a pewnym obiektem, o którym się coś

2 Wszystkie cytaty z pism Cypriana Norwida podaję za: C. Norwid (1971-1976). Po skrócie PW (Pisma wszystkie) umieszczam cyfrę rzymską, lokalizującą numer tomu, po niej zaś arabską, wskazującą na numer strony.

${ }^{3}$ Na podkreślenie - w związku z powiązaniami między nadzieją a rolą poety-kapłana - zasługuje fakt, że Norwidowska koncepcja kapłana znacznie uprzedzała poglądy Yves’a Congara OP (1953), które znacząco wpłynęły na Sobór Watykański II. Dla Congara nie tylko duchowni, lecz również świeccy mają udział w funkcji kapłańskiej, prorockiej i królewskiej Kościoła. Zdaniem Norwida, każdy człowiek jest powołany do kapłaństwa; poeta dostrzega w dziecku z wiersza Człowiek zarazem jego królewskość (,Znać, że Pan z p a nów - służbą uprzedzony, / Skinieniem rządzi, świeci bez korony”, PW I 271), jak i kapłaństwo (,Znać, że i K a pła n, bo ileż to razy / Domowe swary godzi bez obrazy", PW I 271).

4 Poza krótką „notatką” Mariana Stali (1998) wydrukowaną w „Tygodniku Powszechnym" i pastoralnymi refleksjami ks. Antoniego Dunajskiego (1996) wokół wymowy Mszy dziejów i kapłaństwa nadziei. 
orzeka. To orzekanie stanowi treść tej relacji; w strukturze logiczno-syntaktycznej predykatu mieć nadzieję, że ta treść jest jego argumentem przedmiotowym. W niektórych wypadkach (np. gdy relację nadziei wyraża się zwrotem mieć nadzieję na_) obiekt nadziei, pokrywając się z jej przedmiotem, ma charakter zdarzeniowy. W sensie logicznym zatem nadzieja jest relacja czteroargumentową, gdzie trzecim i czwartym argumentem jest treść przedmiotowa wraz z jej logicznym dopełnieniem.

Podstawowy komponent struktury pojęciowej wyrażeń z pola nadziei ma charakter epistemiczny. Już Arystoteles traktował nadzieję m.in. jako typ naszej wiedzy ${ }^{5}$, podobnie - jak się zdaje - patrzył na nadzieję Ludwig Wittgenstein (1997, s. 572-583 nn.), który widział w niej zarówno stan umysłu, jak i pewien fenomen ludzkiego życia. Nadzieja (ujmując ją pojęciowo) jest takim stanem niewiedzy co do zajścia pewnego stanu rzeczy, w którym jej podmiot jest gotów powiedzieć, że nie wie o niczym takim, co wiedząc, byłby gotów powiedzieć, że zajdzie stan przeciwny do stanu rzeczy stanowiącego przedmiot nadziei. Istotnym składnikiem struktury semantycznej wyrażeń z pola nadziei jest ich treść presuponowana, która stanowi koniunkcję wykraczającej poza wiedzę podmiotu wiedzy o możliwości zajścia - jeżeli zajdzie stan rzeczy będący przedmiotem nadziei - czegoś, do czego stosunek aksjologiczny podmiotu jest dodatni, i woli podmiotu, żeby to coś zaszło ${ }^{6}$.

\section{II}

Mówienie o nadziei w pismach Norwida odbywa się na różne sposoby. Najczęstszą i najczytelniejszą strategią komunikacyjną wyrażania doświad-

5 „Aristoteles setzt die Hoffnung in Beziehung zu Wahrnehmung und Gedächtnis: «Das Gegenwärtige ist Gegenstand der Wahrnehmung, das Zukünftige gehört der Erwartung an und das Vergangene dem Gedächtnis». Dabei betont er die rationale Komponente $\dot{\varepsilon} \lambda \pi i ́ \zeta$, so daß er sogar gelegentlich von einer «Wissenschaft des Voraussehens» spricht. Wie die Furcht gehört auch die Hoffnung zu den Affekten ( $\pi \dot{\alpha} \theta \eta)$, die Aristoteles ontologisch als gedrücktes bzw. gehobenes Gestimmtsein der Seele interpretiert. Beachtenswert ist, daß er die Hoffnung wird die «gute Erwartung» lediglich als Folge der Tugend neben guter Einsicht, gutem Gedächtnis und anderem erwähnt” (Ritter 1974: 1158).

${ }^{6}$ Nie ma tu miejsca ani na wykazywanie niesprzeczności, ani na pogłębianie tego zarysu struktury pojęciowej nadziei, nie to zreszta jest przedmiotem niniejszego artykułu, który na podstawie pism Norwida koncentruje się wokół tekstowego sposobu mówienia o nadziei. Powyższe przybliżenie semantyczne ma tu stanowić jedynie pewne tło dla tego, co o nadziei pisze Norwid. Jeżeli zaś chodzi o sformalizowane reprezentacje semantyczne wyrażeń z pola nadziei por. Sobotka 2006: 93-130. 
czeń wewnętrznych jest ich nazywanie wprost. Nadzieję albo jej brak komunikuje się więc za pomocą wyrażeń z kształtem nadzieja. Są to jednostki języka wraz z ich wariantami operacyjnymi, takie jak nominalizacja nadzieja, zwroty mieć nadzieję, że_, być [czyjąś] nadzieja bądź konstrukcje jednostek, jak np. dawać [komuś] nadzieję, że_, [robić coś] w nadziei, żywić nadzie$j e^{7}$. Poetycki język Norwida wykazuje w tym względzie ogromną produktywność, a zarazem kreatywność; wśród wyrażeń werbo-nominalnych znajdziemy takie, które albo rzadko się pojawiają w języku ogólnym, albo należą wyłącznie do idiolektu poety: kupić [coś] nadzieja, wlać nadzieję życia, wyrywać wschodzqce nadzieje, zolbrzymiać nadzieję, itp. Norwid chętnie sięga również po wyrażenia, które już w drugiej połowie XIX wieku uważane były za przestarzałe bądź wychodzące z użycia, jak np. iścić [czyjeś] nadzieje albo w formie dokonanej położyć $w$ [kimś] nadzieję. Pod wieloma względami bardzo interesujący wydaje się Norwidowski zwrot być przy nadziei, którym poeta, świadomie nawiązując do jego dawnego znaczenia 'MIEć nadzieję', deleksykalizuje ustalony już w jego czasach związek frazeologiczny o znaczeniu 'być w ciąży'.

Wśród przymiotnikowych określeń nadziei pojawiają się w pismach Norwida wyrażenia ${ }^{9}$ informujące o referencji jej podmiotu (swoja, twa), nieidentyfikujące (niejaka), temporalne (nowa), wnoszące do grupy imiennej informację czasową (wieczna) bądź ilościową (jedna), określające stopień prawdopodobieństwa zajścia oczekiwanego stanu rzeczy (błaha), identyfikujące sposób przeżywania nadziei i towarzyszące jej zachowanie (cicha),

7 Szczegółowy wykaz wyrażeń z ciągiem nadzieja w pismach Cypriana Norwida wraz z danymi frekwencyjnymi i lokalizacjami przedstawia tabela zamieszczona na końcu tego artykułu.

${ }^{8}$ Por. hasło nadzieja w SJPLin. Kontekst, w którym pojawia się omawiana konstrukcja, pochodzi z listu Norwida do Augusta Cieszkowskiego: „1865. Na Rusi Polskiej, to jest w kraju znachorów i wróżek (z czego się Polacy bardzo cieszą, a co mi jest bolesne, boć nie tylko takie promyczki cudów i proroczości, ale istne cuda są dla n i e w ie r n y ch, nie dla czujnych a praw y ch) - w kraju tedy onym, w 1859 r. było proroctwo, że ponieważ niezwykła ilość kości wyorywa się i bieleje dziwnie na polach, tedy będzie «krwawe żniwo i prześladowanie»; że to był czas tryumfu Towarzy[stwa] Rolni[czego], wszyscy byli przy nadziei i nikt w one znachorów i wróżek słowo nie wierzył” (PW IX 152).

${ }^{9}$ W tych przypadkach, w których łączą się one z jednostkami języka (np. „mogę mieć niejaką nadzieję, iż zatrudnienia praktyczne nie przedstawią się słabym siłom jako niepodobieństwo ostateczne”, PW VIII 168) nie determinują one „składnika” nominalnego, lecz wskazują na charakter wyrażenia predykatywnego (por. też Frege 1977: 52-53). 
wskazujące na jakość momentu początkowego przeżywania nadziei (pięknie wschodzqca), zawierające dodatkową informację o typie i pochodzeniu obiektu i/lub przedmiotu (niebieska, bliższa), waloryzujące sam stan i jego wpływ na człowieka (dobra ${ }^{10}$, słodka).

Frekwencja ${ }^{11}$ wyrażeń z kształtem nadzieja dostarcza interesujących spostrzeżeń, wiele mówiących o samym poecie i jego kondycji duchowo-psychicznej. Najmniejszą ich liczbę notują teksty pochodzące z okresu pobytu w Zakładzie św. Kazimierza (4) i z czasu wyprawy do Ameryki (5). Trudno zapewne przychodziło poecie mówienie o nadziei, kiedy nie miał widoków na poprawę własnego losu i - jak można przypuszczać - doświadczał jej bardzo mało w tych momentach swojego życia. Niska frekwencja wyrażeń odnoszących się do nadziei w schyłkowych latach życia Norwida nie może być jednak argumentem przemawiającym za załamaniem się świata wartości, który był tak bardzo charakterystyczny dla jego twórczości dojrzałej ${ }^{12}$. W tym okresie repertuar wyrażeń z pola nadziei wciąż pozostaje aksjologicznie nacechowany - widać w nim jakiś rodzaj uspokojenia, ale bynajmniej nie rezygnacji, według Norwida bowiem zawsze istnieje możliwość, a ostatecznie nawet i konieczność złożenia nadziei w Bogu (por. PW VI 120). Jednakże w okresie poprzedzającym ostatnie lata życia poety (1870-1876) przeważają

10 Połączenie dobra nadzieja jest archaizmem, śladem dawnego, staropolskiego jej znaczenia, kiedy mogła ona wskazywać na wszelkie oczekiwanie; za pomocą operatorów dobry, zły określało się, jaki może być efekt tego oczekiwania (por. Sobotka 2006: 179-182).

${ }^{11}$ Kształt nadzieja pojawia się w pismach poety zaledwie 120 razy; na twórczość poetycką przypada 40 wyrażeń z tym kształtem, na prozatorską - 80 (dane te pochodzą z własnej ekscerpcji materiału Norwidowskiego; nie obejmują one notatek poety, w których ciąg nadzieja pojawia się kilka razy w różnych kontekstach). Dla porównania Słownik języka Adama Mickiewicza notuje aż 438 użyć nadziei we wszystkich pismach autora Dziadów. Norwid jednak zdecydowanie częściej niż Mickiewicz (oczywiście relatywnie rzecz ujmując) posługiwał się wyrażeniami z pola nadziei w znaczeniu wartościującym, nadawał im przy tym - jak to zobaczymy niżej - bardzo często cechy cnoty teologicznej.

12 Pisze np. Norwid w liście z Nowego Jorku do Aleksandra Jełowieckiego (PW VIII 215-216): „wątpię już o [...] wzajemnościach ludzkich dla siebie”, i dalej: „osycha wszystko we mnie, muszę mieć stosunki z ludźmi, którym wierzyć nie mogę, którzy kochać nie dają się". W dalszej części tego listu uskarża się na cierpienie spowodowane zranieniem ręki, „spalone usta”, „,nadwerężony słuch”, ciemności, które zamąciły oczy itd., a kończy go dramatycznym pytaniem: „Co mam czynić - gdzie umrzeć?”. Z kolei w korespondencji z lat 1977-1883 wśród osobistych wyznań mówi Norwid o klęsce, jaką poniósł (PW X 92), kapitulacji, o „głowie złamanej” (PW X 96-97) itp. 
takie użycia (9), które świadczą o zmianie poziomu aksjologicznego nadziei: po pierwsze, $\mathrm{z}$ formalnego punktu widzenia zwroty z kształtem nadzieja mają najczęściej wypełnione na powierzchni miejsce dla jej przedmiotu (co może świadczyć o tym, że odnoszą się one do nadziei codziennej, konkretnej i powszedniej, por. niżej), a po drugie - tym przedmiotem są dla poety już nie sprawy o charakterze transcendentnym, sakralnym, lecz kwestie finansowe i pieniądze, które Norwid stara się pozyskać ze sprzedaży cennych rysunków itp. (por. PW X 36, 44). Mógł to być istotnie okres, w którym ze względu na dążenie do stabilizacji nadzieja poety koncentrowała się wokół zabezpieczenia własnego bytu.

Największą z kolei frekwencję wyrażeń z pola nadziei obserwujemy w tekstach napisanych w szczytowym paryskim okresie twórczości poety - w pismach z lat 1854-1869 Norwid aż 58 razy używa wyrażeń z kształtem nadzieja; o ponad połowę mniej wynotowujemy z utworów pochodzących z czasu wędrówki po Europie, ale wraz z użyciami z pierwszego pobytu w Paryżu jest ich już 38, co może świadczyć o tym, że choć sytuacja poety nie była wówczas taka, jakiej by oczekiwał, to w jego sposobie patrzenia na świat nie brakowało nadziei, czemu dawał wyraz w swojej twórczości.

W popularnych słownikach synonimów i wyrazów bliskoznacznych wskazuje się na różne wyrażenia znaczeniowo zbliżone do leksemów z pola $n a-$ $d z i e i$. Jestem jednak przekonany, że właściwe i świadome użycie tych ostatnich skutecznie blokuje możliwość ich zastąpienia w jakimkolwiek kontekście przez inne wyrażenia. Potwierdzają to również przykłady Norwidowskie. Najbliższe ze względu na właściwości składniowo-semantyczne jednostkom z pola nadziei są słowa z pól, których centrum stanowią orzeczniki łudzić się, $\dot{z} e_{\text {_ }} \mathrm{i}$ liczyć (na to), $\dot{z} e_{-}$. Są to jednak w pismach Norwida grupy stosunkowo nieliczne ${ }^{13}$ i zaopatrzone we właściwą im porcję sensu, uniemożliwiającą ich wzajemną zastępowalność. Nieco dalej na osi pokrewieństwa semantycznego sytuują się wyrażenia z rodziny spodziewania się, ufania i oczekiwania. Te zaś jednak Norwid traktuje raz jako znaczeniowo pojemniejsze, innym razem - węższe od nadziei i pozostałych elementów jej pola. Pisze na przykład, że gdyby pozbawić nadzieje jej pierwiastka znaczeniowego cnoty teologicznej, sytuowanej w jednym szeregu z wiarą i miłością, to spadłaby ona do zwykłego spodziewania (por. PW VII 13). Ufanie wydaje się zdaniem Norwida wy-

${ }^{13}$ Czasownik tudzić się jest reprezentowany w pismach Norwida 12 razy (w tym jedno użycie imiesłowowe), natomiast liczyć na_lize_ 38 razy. 
rażeniem pozostającym w stosunku hiperonimii do nadziei (zob. PW IX 222), z kolei w oczekiwaniu zawarta jest pewna sugestia pragmatyczna, że jego podmiot ma prawo do tego, aby coś zaszło, czego pozbawiona jest pokorna, szukająca prawdy nadzieja (por. np. użycia w listach poety).

Norwid mówi również o nadziei, wykorzystując do tego niedefinicyjne elementy znaczeń wyrażeń języka, kojarzonych z 'nadzieją'. W języku ogólnym konotację nadziei najczęściej niesie leksem zielony, u Norwida jednak taka konotacja przywoływana jest tylko raz (zob. PW VI 20), i to w użyciu, wobec którego sam narrator tekstu wyraźnie się dystansuje (por. Teleżyńska 1994: 140). O konotacjach nadziei w pismach Norwida, które stanowiłyby utrwalone i ustabilizowane społecznie cechy pragmatyczne wyrazów nie ma więc mowy, da się jednak wskazać leksemy, które w pewnych tekstach, poprzez różne odwołania do skojarzeń powiązanych dość skomplikowanymi sieciami znaczeniowymi z pojęciem nadziei, konotują nadzieję kontekstowo. Do leksemów konotujących nadzieję w poezji Norwida z wielką ostrożnością zaliczam: p ew ne uży ci a tęczy, która być może „uskuteczni, co zaręcza” (por. PW I 54), zorzę, która ma być znakiem wiecznej przyszłości (PW I 74), cyprys jako symbol nadziei życia wiecznego (por. PW I 152), gwiazdę (zob. PW VIII 38), niekiedy po prostu samo światto (PW VIII 214), ale przede wszystkim promyk i wyrażenia należące do jego rodziny (por. PW IX 53) ${ }^{14}$. W tym obrazowaniu widać przeważającą rolę leksyki związanej ze zjawiskami świetlnymi, co nie dziwi, gdyż bywają one powszechnie kojarzone w kulturze judeochrześcijańskiej z nadzieją (por. Sobotka 2006: 218-228). Raz

14 O powinowactwie dla poety nadziei i promienia być może świadczy decyzja translatorska samego autora widoczna w jego francuskim przekładzie wiersza Do J.K. (por. PW I 354-355). Polskiej frazie „Gdy człowiek zwątpił o pisanych dziejach, / Że satelitem są w wiecznych nadziejach" (ibidem, s. 354) odpowiada w wolnym tłumaczeniu Norwida francuska - „Quand l'homme a douté si l'histoire écrite / Est un rayon éternel d'un monde satellite..." (ibidem, s. 355). W wersji francuskiej wyrażenie wieczne nadzieje zostało przetłumaczone jako un rayon éternel, dosłownie 'wieczny promień, ale rzeczownik rayon zwłaszcza w kontekście przymiotnika éternel niesie, m.in. poprzez wyrażenie un rayon d'espérance, wyraźną konotację nadziei, czytelną nawet we współczesnym francuskim języku ogólnym. Norwid jednak miał w tym wypadku i inne konstrukcje do wyboru (np. dosłowną un espoir éternel), decydując się więc na un rayon éternel mógł kierować się skojarzeniami właściwymi dla jego idiolektu. Konotacja nadziei zawarta w Norwidowskim wyrażeniu promyczek i słowach z jego rodziny być może jest efektem wpływu języka francuskiego na język poety. Nie pierwszy to zresztą wyraz z leksykonu Norwida, który zdradza takie zależności (por. Sobotka 2004-2005: 184). 
jeszcze jednak chciałbym podkreślić, że zupełnej pewności, czy wymienione leksemy istotnie - nawet z zastrzeżeniem, że nie ma w tym konsekwencji konotują nadzieję, i na jakich to się odbywa zasadach, mieć nie możemy ${ }^{15}$.

Niejednokrotnie całe obrazy tekstowe - zwłaszcza, jeżeli dodatkowo towarzyszy im wsparcie systemowych środków wyrażeniowych - dają się zinterpretować jako nośniki ukrytych sensów, mogących wskazywać na ślady doświadczenia nadziei. Przyjrzyjmy się fragmentom wiersza Cypriana Norwida Psalm wigilii (PW I 90-92):

O! dzięki Tobie, Ojcze ludów - Boże,

Że ziemię wolną dałeś nam i nagą;

Ani oprawną w nieprzebyte morze, Ni przeciążoną gór dzikich powagą, Lecz jako piersi otworzoną Boże...

$[\ldots]$

I za to jeszcze dzięki Ci, o Panie, Że człek się ówdzie laurem nie upoi, Ani go wiatrów ciepławych głaskanie Prze-atłasowi w nicość - i roztroi

Na drzew i kwiatów motyle kochanie!

Strzeliście w Niebo spojrzy on ku Tobie, Który przez stajnię wszedłeś do ludzkości, I w grobie zwiędłych ziół leżałeś w żłobie, I w porze ziemskich próżnej zalotności, I kiedy cały świat się tarzał w grobie.

Do Ciebie Ojcze-Ojczyzn się podnosim W tym to ubóstwie naszym bardzo sławnym I w tej nadziei, co po skrzydeł osiém Przybiera co dzień, i w płaczu ustawnym, I w bólach, które tak mdło jeszcze znosim. [...]

15 Zawsze istnieje groźba, że ten i ów fragment został przez nas niewłaściwie odczytany i zinterpretowany, że przy przypisywaniu mu pewnej cechy pragmatycznej zatoczyliśmy zbyt szerokie koło hermeneutyczne, uruchamiając wykraczające poza treść intencjonalną konteksty interpretacyjne. 
Cały wiersz ma formę modlitwy dziękczynnej skierowanej do Boga. Podmiot mówiący dziękuje m.in. za ziemię, na której Bóg osadził Polaków, oraz za to, że naród ten „laurem się nie upoi” i nie „prze-atłasowi”. Oba te określenia wskazują na swoistą cechę, polegającą prawdopodobnie na braku dumy bądź pychy z własnych osiągnięć czy zwycięstw. Odczytanie to wiąże się ze szczególnymi konotacjami słów laur i attas. W miejsce pychy Polak z wiersza Norwida, zwracając się ku potężnemu Bogu, „strzeliście w niebo spojrzy” i podniesie się (wstanie z prośbą) do Boga, Ojca-Ojczyzn „w nadziei, co po skrzydeł osiém / Przybiera co dzień" ${ }^{16}$.

Obraz strzelistego spojrzenia w górę ku niebu poprzedza w wierszu samą czynność zapewne metaforycznie rozumianego wznoszenia się do Tego, „,który przez stajnię wszedł do ludzkości”; można go łączyć z wiarą, nadzieją czy zaufaniem oraz miłością z kilku powodów. Z nadzieją łączy go postawa bohatera, który jest pokorny i kieruje się ku Bogu w pełnej zaufania nadziei. Akt nadziei według Josefa Piepera (2000: 158-159) przyporządkowany jest pokorze, wiążącej się z poznaniem i towarzyszącym mu uznaniem niewyrażalnego dystansu, który dzieli wszechwiedzącego Boga od człowieka, którego wiedza jest ograniczona. Przymiotnik strzelisty nawiązuje najprawdopodobniej do aktu strzelistego, którym w chrześcijaństwie jest podniosła, zapewniająca stałą łączność z transcendencją oraz pomoc w każdym momencie życia, modlitwa ufności do Boga, Jezusa, Maryi czy świętych. Akt strzelisty to pokorne zwrócenie się m.in. w wierze, miłości, ale i nadziei ku Absolutowi i Jego porządkowi, to również akt afirmacji. Podobny obraz odnajdujemy w wierszu Do panny Józefy z Korczewa, w którym poeta umieszcza w podniebnym klasztorze zamiast dzwonu, symbolizującego głos Boga, przypominającego o Tajemnicy Wcielenia i o nadziei wiecznie trwającej liturgii niebieskiej (por. Forstner 1990: 397 nn.), ,powietrzne rozgłosy / Aktów strzelistych" (PW I 354). Motyw spojrzenia w górę to niekiedy u Norwida, a także w ikonografii chrześcijańskiej topos nadziei, której szuka się w niebie. W Pięciu zarysach, „Wiesław w ciche pozierał niebiosy, / Jak człek,

16 Zdaniem J. W. Gomulickiego (zob. Norwid 1966: 343) nadzieja ta ma osiem skrzydeł: „tzn. więcej nawet od serafinów, które miały tylko po sześć skrzydeł”. W obrazie tym nie chodzi jednak o serafinów, lecz o osiem błogosławieństw, w których Chrystus wyróżnia m.in. ludzi ubogich $w d u c h u$, cichych, czystego serca (por. Mt 5,1-12). Dla nich bowiem istnieje nadzieja królestwa niebieskiego (życia wiecznego). 
którego bliższa ${ }^{17}$ nadzieja ucieka" (PW III 497); spojrzenie ku niebu to przewodni motyw poematu Assunta, w którym poeta szuka możliwości, a może i nadziei właśnie, przezwyciężenia poprzez miłość poziomowości życia.

\section{III}

Już tylko na podstawie powyższego przeglądu sposobów wyrażania nadziei w twórczości Norwida można wyciągnąć wniosek o oryginalnym podejściu poety do tego zagadnienia. Norwid w istocie rozwija własną koncepcję nadziei, która zakorzenia się w chrześcijańskiej wizji świata. W sposób niekonwencjonalny ujmuje teorię cnót, co objawia się m.in. w zaproponowanym przez niego podziale fenomenu nadziei ze względu na typ i rodzaj ładunku aksjologicznego jej przedmiotu. W liście do Konstancji Górskiej próbuje pokazać pewne formalno-znaczeniowe kryteria, na podstawie których możliwe jest różnicowanie nadziei:

Zapewne, Droga Pani, że wszystko czarne na świecie, jak mi to Pani pisze w listku swoim. Ależ powiedziane nam było i nie zakryte, że światłość w ciemnościach świeci - a ciemności Jej nie ogarnęły!

Tak jest i z tymi czarnościami świata - światłość w nich małym promyczkiem świeci zawsze i one już nigdy ostatecznie nie ogarną.

Nie tylko Wiara i Miłość, ależ Droga Pani, i Nadzieja jest także cnotą jak Wiara i Miłość. Zapewne, że jeżeli ja pisząc to i napisawszy poszlę do domu Pani, i mam nadzi ej ę, że dojdzie, to nie jest to $\mathrm{Nadzieją-}$ - c notą, o której mówię.

Widziała Pani sama na przykład z tego, co pod oczyma Pani działo się z panią Essakoff $\mathrm{i}$ jej bratem ${ }^{18} \ldots$ To! była ta $\mathrm{Nadzieja-cnota,} \mathrm{która} \mathrm{jest} \mathrm{z}$ Wiarą i Miłością stawiona w rzędzie jednym. (PW IX 53-54)

Świat - nawet jeżeli z pozoru wydaje się, że jest całkowicie ogarnięty przez zło (ciemności ${ }^{19}$ ) i czarności, które zapewne - ze względu na ich ce-

17 Zapewne chodzi tu o nadzieję ziemską, pokładaną w ludziach, taką, której szuka się na ziemi, w swoim najbliżs z y m otoczeniu.

18 Mowa tu o niemal cudownym ocaleniu brata generałowej Esakow z więzienia rosyjskiego. Norwid wstawiał się za nim, pisząc nawet list do Napoleona III; ostatecznie został on uwolniony dzięki protekcji Delfiny Potockiej (por. PW XI 95).

19 Por. bardzo interesujący wywód na temat znaczenia Norwidowskiej ciemności przeprowadzony przez Barbarę Sawicką-Leszczuk (2003: 100 nn.). Jej zdaniem, „ciemność [...] symbolizuje nie tylko niewiedzę, obejmującą niejako potencjalne poznanie, ale 
chy konotacyjne - oznaczają sprawy przygnębiające i prowadzące do negacji dobra - rozpaczy - rozświetlają jednak, jak uczy Ewangelia św. Jana (por. J 1,1 nn.), promienie światłości, co dla Norwida staje się źródłem nadziei. Poeta odróżnia nadzieję-cnotę, która jest konsekwencją tego, że Bóg wkroczył w świat i rozświetlił panujące w nim ciemności, od nadziei-powszedniej, odnoszącej się do bliższej bądź dalszej niewiadomej codziennego życia.

Najczęstszym wyróżnikiem obu rodzajów nadziei od strony graficznej jest wielkość litery. Norwid niejednokrotnie posługuje się majuskułą, kiedy pisze o nadziei-cnocie.

Z kolei od strony formalno-znaczeniowej oba typy różni wypełniona (w przypadku nadziei powszedniej) bądź z a z w y c zaj wyzerowana (kiedy poeta mówi o nadziei-cnocie) pozycja przedmiotowa oraz semantyczna autonomiczność rzeczownika nadzieja i silna kompletywna pozycja czasownika mieć w niezleksykalizowanym, lecz mającym charakter werbo-nominalny wyrażeniu mieć nadzieje, wskazującym na nadzieję-cnotę ${ }^{20}$. Z wypowiedzi Norwida o charakterze osobistym wynika, że czyni on przedmiotem nadziei powszedniej najczęściej sprawy konkretne, związane z kontaktami z innymi ludźmi, z ich nawiązywaniem, podtrzymywaniem itp. (PW VIII 31, VIII 38, VIII 79, VIII 215, IX 54, IX 390-391) ${ }^{21}$, zdobywaniem środków finansowych (PW VIII 218, IX 239-240, IX 304, IX 347, X 36, X 44), własną twórczością i w ogóle pracą (PW VIII 11, VIII 87, VIII 95, VIII 108, VIII 168), niepodległością narodu (PW VIII 148, IX 116, 340), zdrowiem (PW VIII 67, IX 499), powrotem do kraju (PW VIII 44), poznaniem rzeczywistości (PW VI 79). Ujęcie ich w kontekst nadziei, chociażby nadziei zaledwie powszedniej,

również zło”. Jednym z zadań poety jest zmaganie się ze złem: „kto tworzy - pisze Norwid - Dwoma ramiony w cienie nieustannie godzi” (PW III 594-595).

${ }^{20}$ Innymi słowy, nie mielibyśmy w takim przypadku do czynienia z właściwą jednostką języka. Graficznie, zapisując odpowiadające temu wykładnikowi pojęcie, oddają to kapitaliki: 'MIEĆ nadzieję'.

${ }^{21}$ Znamienny pod tym względem wydaje się przykład pochodzący z listu do Marii Trębickiej, w którym Norwid pisze: „Rozmowa Pani z p. M[arią] powróciła mi jakiś cień nadziei - jest to wiele, o, wiele! Wiele, że wierzę temu, co Pani tylko mogłaś zrobić” (PW VIII 25). Rozmowa oprócz tego, że sama może być przedmiotem nadziei (jak w przykładach, których lokalizacje są przywoływane w tekście głównym), to ma dla poety również zdolność ,ppowracania” - przywracania nadziei, o której można było sądzić, że się ją straciło. Norwid nie pisze, że rozmowa powróciła nadzieję, lecz cień nadziei. Wyrażenie to wskazuje na 'odrobinę nadziei', co już samo w sobie musi być jednak dla poety znaczące, skoro autor listu pisze, że to ,wiele, o, wiele”. 
świadczy o wadze takich wartości w życiu poety. Warto tu podkreślić, że to ostatecznie nie przedmiot wpływa na typ przeżywanego doświadczenia, a składa się na to wiedza, wola i zaangażowanie aksjologiczne podmiotu. Hrabina z dramatu Aktor, mówiąc, że „Nadzieją bywa w drugich, co w nas jest tęsknotą!" (PW IV 329), daje do zrozumienia, że to, za czym ktoś tęskni, może być z kolei przedmiotem nadziei kogoś innego.

Przedmiot nadziei-cnoty nie jest $\mathrm{z}$ reguły na powierzchni wyrażany wprost (niejednokrotnie wymaga rekonstrukcji, wydobycia na powierzchnię poprzez interpretację), przez co nabiera on charakteru ogólnego, uniwersalnego, a dzięki powiązaniu tej nadziei z sacrum ma także - jak to zobaczymy niżej - charakter transcendentny. Od strony kontekstowej nadzieja jako cnota stawiana jest $\mathrm{w}$ jednym szeregu z pozostałymi cnotami teologicznymi - wiarą i miłością. Norwid nawet pisze, że „Nadzieja wszakże bez dwóch drugich współ-cnót, współ-sił, współ-pojęć, z proroczej nagle wysokości na potoczne spada spodziewanie [...]" (PW VII 13). Poeta podkreśla tu dwie rzeczy: proroczy aspekt nadziei-cnoty, wybiegający w przyszłość, związany z jeszcze niedostępną innym, widzianq jakby $w$ zwierciadle, niejasno (por. 1 Kor 13,12) wiedzą o sacrum (por. Puzynina, Sobotka 2002: 13 nn.), oraz jej związek znaczeniowy z pozostałymi współ-cnotami. A w liście do Józefa Zaleskiego pisze, że „kiedy nie ma $\mathrm{Nadzi}$ i jako cnoty, Wi ary jako siły, Miłości jako prawdy, tylko jest spodziewanie się, czyli fortuna - wierzenie formalne i miłowanie, jak się podoba..." (PW VIII 265). Rzeczownik fortuna w przytoczonym fragmencie ma zapewne wskazywać, że nadzieja pozbawiona statusu cnoty skazana jest na los czy przypadkowość, a przedmiot, którego ziszczenia się oczekuje, nie wybiega poza sprawy doczesne, mające przynosić szczęście doraźne i jednostkowe oraz pomyślność.

Wydaje się zatem, że zdaniem Norwida zdefiniowanie nadziei-cnoty bez odniesienia się do wiary-cnoty i miłości-cnoty byłoby niepodobieństwem. Przy czym w lekcji I O Juliuszu Stowackim poeta przyznaje, że odkrycie tych zależności stało się udziałem ludzkości dzięki wkroczeniu Boga w historię świata, która rozpada się na okres przed Wcieleniem, zdominowany przez samą nadzieję i okres po tym eschatologicznym wydarzeniu, pozostający pod znakiem wiary, nadziei i miłości: 
Nadzieja [u Betlejemskiego żłobu - P.S.] wszelako odsłoniła nam przez to samo opony ${ }^{22}$ i pokazała pierwociny całokształtu architektury swojej, objawiła się niejako i stała się je d n ą z trzech cnót, gdy pierwej była j e d y ną. (PW VI 409).

Nadzieja-cnota, która została objawiona „u Betlejemskiego żłobu” dzięki dziełu zbawienia, nie tylko odsłania ,pierwociny całokształtu architektury swojej”, czyli swoje źródło i właściwe miejsce oraz strukturę w planie eschatologicznym historii, lecz także wraz z tym wydarzeniem, dzięki narodzinom chrześcijaństwa, staje w jednym szeregu obok wiary i miłości. Człowiek przed-Chrustusowy, nie znając, zdaniem Norwida, łaski wiary i miłości, w nadziei oczekuje Wcielenia, a po wypełnieniu się tej Tajemnicy, jak Abraham, wzmocniony miłością wierzy w nadziei, że spełni się dana mu obietnica (por. Rz 4,18-21). Moment objawienia się nadziei-cnoty Norwid w studiach O Juliuszu Słowackim nazywa „Niedzielą nadziei”, po niej zaś przychodzą jej ,poniedziałki”, „dni powszednie” (por. PW VI 409-410, VI 418), gdyż nadzieja, ,jakkolwiek spełniwszy się za przyjściem chrześcijaństwa, nie przestała jednakże być nadzieją” (PW VI 417), a „znowu zeszła do dni powszednich swoich" (PW VI 417), w których ,,jest też wiele do walczenia” (PW VI 418).

O tym, że dzielenie doby chrześcijańskiego społeczeństwa osobno na dobę pozostająca pod dominującym wpływem wiary bądź miłości czy nadziei jest czynnością jałową, skazaną na niepowodzenie, a być może i niesłuszną, świadczy również wypowiedź Norwida, w której poddaje on krytycznej ocenie koncepcje historiozoficzne, odrzucające wzajemne zależności trzech cnót i ujmujące je w planie dziejów w sposób odrębny i jednostkowo ${ }^{23}$ :

podobno wszystkie doby chrześcijańskiego społeczeństwa w jednej z trzech cnót węgielnych ${ }^{24}$ rozmiłowały się szczególnie, zapominając, iż do każdej przez inne jest droga. I oto była doba WIARY bez miłosierdzia i nadziei - i MIŁośCI doba, tak pamiętna z najabsolutniejszego niedowiarstwa, a dziś jesteśmy

22 Tj. zasłony. Narodziny Chrystusa pokazują dopiero właściwą istotę nadziei, odsłaniają nam prawdę o niej jako o wspót-cnocie.

${ }^{23}$ Być może jest to próba dyskusji z koncepcjami millenarystycznymi i mesjanistycznymi, dzielącymi historię na trzy okresy, jak czynili to m.in. w średniowieczu Joachim z Fiore, a w okresie klasycyzmu i romantyzmu Hegel czy Cieszkowski i inni myśliciele epoki.

$24 \mathrm{Tj}$. głównych, fundamentalnych. 
o NADZIEI, lecz - ile dotąd sądzić można - zbyteczną w i a rą nie grzeszymy, a zaś miłości, śmiało powiem, iż brak dość jest widoczny. (PW VII 13).

Źródłem nadziei-cnoty jest Chrystus, a jej przekazicielem i zarazem głosicielem ma być poeta, natomiast nadzieja powszednia jest ściśle związana ze światem i człowiekiem; ta więc jest efektem kalkulacji i oceny doraźnych, niekiedy zmiennych stanów rzeczy, i niewątpliwie możliwa jest taka sytuacja, że ktoś, kto ze względu na pewne warunki nie doświadcza nadziei powszedniej, bo nikt i nic mu jej nie daje, pozostaje w gruncie rzeczy człowiekiem nadziei, którą - dzięki niezgłębionemu Miłosi erdziu, co „trwa na wieki” (zob. PW III 670) - może pokładać w Bogu, i za którą gotów jest ponosić nawet cierpienia:

Proszę mnie nigdy na podobne rozmowy nie wyprowadzać - kocham przyszłość społeczeństwa, któremu służę, i mam $\mathrm{Nadzieję,} \mathrm{za} \mathrm{którą} \mathrm{cierpię,}$ ale nadzieję jako cnotę - bowiem innej nadziei, gdziekolwiek nie zakrywając sobie oczu spojrzę, nikt i nic mi nie da... (PW VI 637).

Nadzieję powszednią, zdaniem Norwida, niejednokrotnie wykazującą znaczeniowe powinowactwa z pocieszeniem (por. np. VIII 388), pokłada się w ludziach i ze względu na nich; oni z reguły są jej dawcami i oni też, obok biegu wydarzeń - losu, mogą na nią wpływać pozytywnie ( $p o w r a-$ cać (PW VIII 25)) bądź negatywnie (wyrywać ją (PW I 7), pić (PW III 663), odbierać (PW X 36)). Niekiedy doświadczenie nadziei wiąże się z różnymi zdarzeniami, których efektem mogą być pożądane, choć z reguły nie nazywane wprost stany rzeczy; tak więc bohaterowie Norwida poktadaja nadzieje $w$ zmianie miejsca (na takie, w którym panuje sprzyjający klimat) i w upływie czasu, wreszcie w sen, podczas którego może minie gorączka (PW VI 120) ${ }^{25}$. Nadzieję mogą rodzić konkretne treści, które ze względu na

25 Przykłady te potwierdzają początkową intuicyjną definicję nadziei zaproponowaną w tym tekście, w której związany z nadzieją dodatni ładunek aksjologiczny nie odnosi się wprost do przedmiotu (który niejednokrotnie może mieć charakter neutralny bądź nawet negatywny), lecz do związanych z nim konsekwencji. Z punktu widzenia podmiotu nadziei dodatniemu wartościowaniu podlegają możliwe przyszłe konsekwencje przedmiotu nadziei, co Leibniz oddaje formułą, że spes to „opinio boni futuri” (Leibniz 1975). 
zawarty w nich przekaz bądź ,zawierają nadzieję” (PW III 60), bądź są dla czytelników „promyczkiem nadziei” (PW VIII 388) albo przywracają „cień nadziei” (por. przyp. 21); zdaniem poety pewne słówka i słóweczka (PW V 228 i 231) mogą sprawiać, że dzięki nim ktoś zacznie doświadczać tego stanu. Natomiast źródłem, darczyńcq (zob. PW III 670), a zarazem powiernikiem nadziei-cnoty - jak to zostało powiedziane wyżej - jest sam Bóg, na którego zawsze możemy się powołać petni cichej nadziei, gdy ziemskie nadzieje zawiodą (por. PW III 512-513). W wierszu Bliscy czytamy:

Bo teraz wszędzie jeszcze Twoje $n$ ie ja

Obejmać musisz sumieniem;

I nie Twój jesteś rozum i nadzieja,

I jesteś Twoim zwątpieniem! (PW II 76)

Jest to gorzka diagnoza rzeczywistości ludzkiej. Człowiek na ziemi „bywa / Zdrowych lat kila... lub parę” (PW II 75), a do tego czas ten naznaczony jest cierpieniem, smutkiem i świadomością własnej znikomości, w czym ludzie gotowi są widzieć nic więcej, jak tylko plagę. Kondycja człowieka zmusza go do obejmowania sumieniem niepewności jego losu i tego, co nie podlega jego wpływowi i od niego nie zależy, życie jest i pozostaje dla nas niewiadomą, i wszystko, cokolwiek chcielibyśmy uprawdopodobnić, w gruncie rzeczy naznaczone jest nie ja niepewności i podległości różnym wpływom. Niepewność ta zresztą jest podstawą nadziei człowieka. Nadzieja i rozum w wierszu to metonimie powierzchniowe, które wskazuja (być może) na to, że zarówno poznanie, jak i wykraczająca poza wiedzę człowieka wiedza-oczekiwanie dane są przez Boga, ludziom natomiast właściwe jest wyłącznie zwątpienie ${ }^{26}$. To Bóg, dawca dobra ostatecznie sprawia, że coś wiemy i że możemy mieć nadzieję. W Memoriale o młodej emigracji Norwid wręcz mówi, że żywienie nadziei (zapewne chodzi tu głównie o nadzieję powszednią) może - gdy nie ma do tego realnych podstaw ${ }^{27}$ - odbywać się kosztem stanowiącej funkcję wiedzy prawdy (por. PW VII 108); taka nadzie-

${ }^{26}$ Które też zresztą może być przedmiotem nadziei, jak w wierszu Pieśń od ziemi naszej (PW I 123-124), gdzie poeta zwątpienie w to, że źli są źli, czyni przedmiotem nadziei, którą kieruje ku Południu. Ważnych rozwiązań interpretacyjnych tego wiersza dostarcza praca Grażyny Halkiewicz-Sojak (1998: 180 nn.).

27 Taką podstawą jest w przypadku nadziei-cnoty - jak to widzieliśmy wyżej - Bóg i Jego słowo. 
ja jest złudna, czcza, a dla Norwida również błaha ${ }^{28}$ (PW V 194), choć ludzie - gdy brak im sił - i taką nadzieją są gotowi się żywić; Norwid pokazuje, że można ich nią nawet kupić (por. PW IV 12). Natomiast w Pieśni społecznej poeta, definiując wolność $^{29}$, wskazuje pośrednio i na cechy nadziei: jej przedmiot jest „w dali” i w związku z tym nigdy nie można mieć pewności, czy się ona ziści, czy też nie. Uzyskanie tej pewności byłoby zdaniem Mariana Stali (1998) równoznaczne $\mathrm{z}$ „objawieniem się” nadziei ${ }^{30}$. Wiedza bowiem (również i wiedza subiektywna, jaką jest pewność) skutecznie wyklucza nadzieję. Potwierdza to także Norwid, kiedy pisze, że gdy człowiek ma nadzieję, to nie wie, a jego niewiedza odnosi się zarówno do tego, czy się spełni pożądany przez niego stan rzeczy, jak i do tego, jakie są prawdziwe mechanizmy, dzięki którym dochodzi do osiągnięcia tego stanu:

Bo jak człowiek zasieje,

To ma ino nadzieję,

Ale nie wie, co w roli

Ziarna one rozwija (PW I 146).

Niepewność jednak może być przezwyciężana, co odbywa się właśnie przez nadzieję i tylko przez nią, zwłaszcza jeżeli jej źródłem jest Bóg, który jako jedyny wie, co rozwija ziarna ludzkiego siewu. Przełamywanie niepewności dotyczy już jednak nadziei-cnoty, o której to właśnie być może pisze Norwid w Pieśni społecznej, że jest pewna swych kolei (por. PW III 346-347),

28 Kolokacja błaha nadzieja jest jeszcze powszechnie używana w XIX wieku w języku ogólnym, notuje ją m.in. popularny Słownik Rykaczewskiego; współcześnie jednak już byśmy tak nie powiedzieli, gdyż błahy utracił swe dawne znaczenie 'czczy, nieugruntowany, nierealny'.

${ }^{29}$ „Wolność bowiem to na dzieja, / Zawsze ona w dali; / Zawsze u niej ja i nie j a / I zawsze się pali” (PW III 347). Koniunkcja,,j a i n ie-ja” wskazuje na paradoks życia, które często w sytuacji epistemicznego wahania dopuszcza sprzeczności. Rzeczywistość naznaczona potencjalnością nie jest w stanie rozstrzygnąć tego dylematu. $Z$ jednej strony skłonni jesteśmy afirmować pewne stany rzeczy, ze względu na wiarę w porządek transcendentny i nasze pragnienia przydawać im wartość pozytywną, z drugiej jednak doszukujemy się błędu czy braku, nadając przedmiotom tych pragnień status niemożliwości.

30 Przytaczam tu ten pogląd, co do którego nie mam jednak całkowitej pewności, że jego źródłem jest myśl Norwida. Przejrzane przeze mnie użycia pewności nie wyrażają tej idei wprost, choć nie jest niemożliwe jej wnioskowanie na podstawie pewnych kontekstów. 
co oznacza, że właściwy, oczekiwany przedmiot tego doświadczenia oraz to, do czego ono dąży i w jaki sposób to się odbywa pod groźbą sprzeczności nie mogą już być naznaczone niepewnością, co oczywiście nie przesądza od razu w i e d z y na temat ziszczenia się tego przedmiotu.

Norwid dwukrotnie przyznaje, że ma nadzieję w Bogu (por. PW VIII 36, VIII 67), co należy rozumieć tak, że nie tylko ją w Nim pokłada, lecz również że On jest jej dawcą, a raz w liście do Marii Trębickiej wyznaje, że w Bogu po to żyt nadzieje (PW VIII 23), co jest w istocie dla Norwida aktem oddania się Najwyższemu. Pod koniec życia koncepcję Boskiego źródła i odniesienia nadziei ujmie $\mathrm{w}$ formie wypowiedzi o charakterze deontycznym. Pochodząca ze Stygmatu, jednego z ostatnich utworów Norwida, dyrektywa „zawsze w Bogu nadzieję mieć potrzeba” (PW VI 120) brzmi niemal jak testament samego poety. Nadzieja sprawia, że przylegamy do Boga i opieramy się na Nim, by osiągnąć szczęście najwyższe ${ }^{31}$, chociażby nie to, co tyle daje radości i sławy (por. PW I 273).

Nadzieja-cnota - w quasi-definicyjnych wypowiedziach poety - ujmowana jest jako „ufanie w konsekwencje prawdy” (PW IX 222), ponieważ - jak pisze Norwid w Głosie niedawno do wychodźtwa polskiego przybytego artysty - „nadzieja jest z prawdy” (PW VII 7). Dla poety korzeniem wszelkiej prawdy, ,jest, był i będzie” (PW VIII 212-213) Zbawiciel, On też jest dawcą nadziei jako cnoty. Norwid w poetyckiej definicji tej nadziei wykorzystuje rzeczownik ufanie, który utworzony został od formy niedokonanej, co w sposób istotny wpływa na jego semantykę, a pośrednio charakteryzuje samą nadzieję, która dzięki analogii do ufania może być traktowana jako stała bądź względnie stała dyspozycja człowieka. Z kolei konsekwencje prawdy należy rozumieć jako to wszystko, do czego ona prowadzi i czemu służy. Norwid nie mówi tu, że widzimy samą prawdę, lecz jedynie jej atrybuty bądź następstwa (moc (PW VII 143), site, odrodzenie i pocieszenie w cierpieniu, por. Puzynina 1993: VIII). To im właśnie ufając, doświadczamy nadziei, która w jej wersji chrześcijańskiej sama staje się moca, dzięki której z kolei możliwe jest osiągnięcie wolności (por. PW III 346-347), i która rodzi wytrwałość i doświadczenie (PW VII 7). Natomiast doświadczając nadziei na podstawie tego, co jest z prawdy, przeczuwamy samą prawdę, do-

31 Por. Thomae de Aquino 1929 oraz zamieszczony w tym wydaniu znakomity komentarz do sześciu kwestii o nadziei (II-II q. 17-22), napisany przez dominikanina J. Le Tilly. 
cieramy do jej Boskich korzeni, niejako dopiero ją antycypujemy, i dlatego ostatecznie nie można utożsamiać nadziei z prawdą, która w przeciwieństwie do nadziei ma charakter faktywny.

W świecie Norwida podmiotem zarówno nadziei-cnoty, jak i nadziei powszedniej, a w pewnym sensie - jeśli przyjąć Boskie źródło nadziei i możliwość jej przekazywania - również jej odbiorca, jest nie tylko pojedynczy człowiek; bywa nim także cała społeczność ludzka lub konkretny naród, jak pokazuje to poeta w lekcjach O Juliuszu Słowackim, gdzie pisze, że nadzieja jest skierowana do „człowieka zbiorowego, narodu i narodowości” (PW VI 410). Mówi w tych prelekcjach również o nadziei człowieczeństwa (PW VI 416), nadziei Ojczyzny (ibidem) i nadziei wieków (PW VI 417). Rzeczowniki Ojczyzna i wieki są metonimicznymi określeniami odpowiednio narodu i ludzkości, tej współczesnej poecie i tej, która żyła dawniej, oraz tej, która dopiero czeka na swoją historię, wciaż pisana przez Przedwiecznego (por. PW VI 417). Zdaniem Norwida możliwa jest więc sytuacja, kiedy wielu ludzi łączy jedno pragnienie i wyrastająca z niego jedna nadzieja. Nośnikiem tej nadziei jest $\mathrm{z}$ jednej strony chrześcijaństwo z jego przesłaniem o charakterze powszechnym, $\mathrm{z}$ drugiej zaś pragnienie wolności jako inherentna cecha narodu (por. PW VII 27).

Historia ludzkości - jak to zostało powiedziane wyżej - stoi pod znakiem nadziei i do nadziei się odwołuje, wszak dzieje „,satelitem są w wiecznych nadziejach" (PW I 210), to znaczy, że nadzieje, których przedmiotem jest wieczność, są ściśle powiązane z dziejami, w pewnym sensie nadzieje obejmują również swym zakresem historię świata. Momentem zwycięstwa nadziei zdaniem Norwida były śmierć i zmartwychwstanie Chrystusa, lecz „Nadzieja, mimo zwycięstwa na Golgocie, odnadzieja się nieraz na powrót" (PW VI 418); nadzieja nie jest więc nam dana w sposób ostateczny i oczywisty; ona pojawia się i znika, zatraca (por. Stala 1998). Dlatego właśnie musimy ciągle podejmować pracę nad ludzką nadzieją, do czego w sposób szczególny wezwani są według Norwida poeci, których określa on kapłanami nadziei (PW VI 409), wskazując jednocześnie, na podstawie powinowactwa w posłannictwie do walki o powiązaną z nadzieją prawdę (por. Puzynina, Sobotka 2002: 16-17), między nimi a prorokami, którzy z kolei część istotnq biora „W Nadziei razem, w Miłości i Wierze” (PW III 456). Szczytowym momentem ich kapłaństwa było głoszone przez nich w orędziu nadziei Wcielenie, które przyniosło spełnienie nadziei „człowieka pojedyńczego” (PW VI 410). 
Po tym wydarzeniu zmienia się ich posłannictwo - „nie tracąc właściwego im kapłaństwa nadziei” (PW VI 411), rozpoczynają oni „we dnie powszednie” (PW VI 418) pracę nad nadzieją pewnej zbiorowości, która doskonałością nie może równać się z doskonałością jednostki, nad nadzieją społeczności i narodu, ,gdzie światłość Pańska nie zajaśniała jeszcze” (PW VI 410), „idą [...] szukać nadziei Ojczyzny” (PW VI 416), która „nie tylko w Chrześcijaństwie się zaczyna, ale zawsze jest ziemią obiecaną, [...] pierwej była zie mią obie cana, potem społecznością obiecaną, a [...] razem i ziemi, i społeczności obiecanej wygląda się” (PW VI 411-416). „Mając oni za jedyną potęgę i środek słowo - pisze Norwid (PW VI 412) - słuszna, iż rozpoczęli od języków”, które starają się przemieniać, uchrześcijańczać, „choćby wytwornością i formą" (tzn. od strony formalnej i stylistycznej), ale głównie jednak w ich warstwie znaczeniowej poprzez gwarantujące zdaniem Norwida prawdę docieranie do pierwotnego sensu ${ }^{32}$, aby mogły one wyrażać epopeję chrześcijańska i nadzieję nowa przynosić (por. PW VI 412), aby wreszcie można było oddawać nimi głębokie treści teologiczne (ibidem) ${ }^{33}$. Słowo ma wspomagać ich w uszlachetnieniu istoty zbiorowości (por. PW VI 416), W walce z pogaństwem, którego przejawem jest dla Norwida $\dot{z} y w i o ł b a r b a-$ rzyństwa - bratobójcza, być może podejmowana dla uciechy obserwatorów, walka chrześcijan, zapewne pozostająca bez związku z droga krzyża i z szerzeniem wiary (por. PW VI 418). Poeta nakreśla więc szczegółowy program pracy nad nadzieją społeczności XIX wieku:

Nie trzebaż to nam jeszcze filozofię uczłowieczyć, politykę i ekonomię uchrześcijanić, praktyki religijne odserdecznić - choćby w nas samych? - salonowe formy uprostodusznić, a rubaszność gminną wznieść nad poziom?! Jeszcze przecież w postępie pogwałconym lub opóźnionym, jakby antropofagi, spychamy starców, a młodzieńcom dostępu nie dajemy, jeszcze bibułą drukowaną zaklejamy sobie oczy, a słowa natury i liter palcem pisanych Bożym czytać zaniechaliśmy. Jeszcze ja sam widziałem, jak czcionkami ołowianymi strzelby nabijano na bratobójczy okrzyk, ale karty narodów rozcinano w biurach kościanym nożem, jak karty książek. Jeszcze się pchamy, jeszcze się wałęsamy, między tą cywilizacją at rady cyjna, której wielka praktyczność jest często wielce nie-

32 Warto zauważyć, że od strony dźwiękowej najbardziej dostrojone do bycia nośnikiem nadziei są według Norwida słowa języków słowiańskich (PW III 564).

33 Najpoważniejsze z nowszych studiów na temat słowa i pracy nad jego przemianą w koncepcji Norwida przynoszą następujące teksty Kudyby (2000), Chlebowskiego (2000), Torunia (2003), Puzyniny (2006: 15-42). 
poczciwa, a pomiędzy naszą ukochaną cywilizacją tradycyjną, której wielka poczciwość jest wielce niepraktyczną, jeszcze, jednym słowem, jesteśmy DOPIERo ludźmi XIX wieku ${ }^{34}$. (PW VI 418)

Trud poety w pracy nad nadzieją innych - o czym warto pamiętać - nie musi w warstwie pragmatycznej prowadzić do tego, że ich twórca sam ma nadzieję-powszednią, co zostało już wyżej zasygnalizowane. W liście do Józefa Bohdana Zaleskiego Norwid wyznaje, że pracuje ,z nałogu naprzód, z Miłości potem, i bez wiela nadziei” (PW VIII 120). Chodzi tu prawdopodobnie o nadzieję docenienia wysiłku twórczego albo od strony jego krytyki, albo - co raczej bardziej prawdopodobne - od strony materialnego zabezpieczenia artyście jego bytu i stworzenia mu dogodnych warunków. Sytuacja, w której twórca pracuje z nadzieją, wymagałaby według poety odmiany catego sztuki kierunku (por. ibidem) i uzyskania przez nią statusu powszechnie użytecznej dziedziny życia.

Żywienie nadziei przez podmiot może być wsparte miłością, której on tak czynnie, jak i biernie doświadcza, a która stymuluje samą nadzieję. Na przykład w Promethidionie mowa jest o tym, że nawet drobne wydarzenie (lada promyk) może zolbrzymiać nadzieję, gdy jej podmiot jest zakochany (por. PW III 443). W Niewoli natomiast poeta wyznaje wiarę, że pomóc cierpiącemu można dzięki wlaniu w niego nadziei życia, w czym niemały udział ma krzepienie takiej osoby miłościa, dzięki której między cierpiącym a wspomagającym go rodzi się głęboka więź empatii (zob. PW III 391).

\section{IV}

Warto z kolei na koniec (i skrótowo) - zważywszy na zarysowane wyżej przybliżenie Norwidowskiego rozumienia nadziei, wzbogacone o koncepcję poety-kapłana nadziei - odpowiedzieć na pytania, które dialogują z tezą o kapłaństwie nadziei samego Norwida. Chodzi tu w zasadzie o spojrzenie $\mathrm{z}$ różnych perspektyw na tę samą kwestię: jak na tle zaprezentowanej kon-

34 Jadwiga Puzynina (2006: 127) dostrzega w tym Norwidowskim passusie również „znakomitą ocenę [jego - P.S.], a równie dobrze i naszej, współczesności”. I tak zapewne jest. Wciąż bowiem - parafrazując poetę - pozostaje aktualna diagnoza Norwida: jeszcze, jednym słowem, jesteśmy DOPIERo ludźmi XXI wieku. 
cepcji Norwid sytuował samego siebie jako twórcę ${ }^{35}$, oraz jak w jej świetle z perspektywy badacza, śledzącego wzajemne związki życia, twórczości i nadziei, przedstawia się kapłaństwo nadziei autora Vade-mecum.

Jako wystarczające kryterium przyjęcia jakiegoś poetę za kapłana nadziei należy przyjąć to, że:

(1) Słowa, które on głosi, muszą być z prawdy, co gwarantuje ich Boskie pochodzenie - ich źródłem powinna być Chrystusowa Ewangelia; inaczej rzecz ujmując, Norwid wymaga, aby były one uchrześcijanione, przy czym od strony formalno-treściowej słowa te winny charakteryzować się semantyczną prostotą i nawiązywać do pierwotnych sensów.

(2) Słowa poety, biorące swój początek w orędziu Chrystusa, mają być skierowane do całej społeczności, muszą zatem przedstawiać wizję ogólna $i$ jakby fenomenologiczna ${ }^{36}$, ponieważ ich głosiciele „d o o gólności chrześcijańskiej, [...] do zbiorowości idą" (PW VI 443).

Norwid wprawdzie w żadnym miejscu nie mówi o sobie, że jest kapłanem nadziei, choć - jak widzieliśmy to wyżej - przyznaje w eseju O miłości ksiag $d$ wie - że jest człowiekiem nadziei jako cnoty (por. PW VI 637). Poeta - jak to można wyczytać z wiersza Modlitwa, jeżeli ma w nim na myśli samego siebie - spełnia pierwsze i możliwe, że również drugie kryterium, nakładane na kapłana nadziei; jego głos ma źródło w Bogu, a być może - jeżeli tylko zostanie on rozwiqzany, o czym się jednak z wiersza nie dowiadujemy - będzie skierowany z jakimś orędziem do innych, co sugerowałoby znaczenie etymologiczne słowa anioł (z języka greckiego ă $\gamma \gamma \varepsilon \lambda$ os 'posłaniec (z wiadomościami), zwiastun [czegoś]'):

Jestem zna mię!...

Sam głosu nie mam - Panie - dałeś słowo,

Lecz wypowiedzieć któż ustami zdoła?

Przez Ciebie - prochów stałem się Jehową,

Twojego w piersiach mam i czczę anioła -

To rozwiąż jeszcze głos - bo anioł woła.

(PW I 136)

35 Wiele światła na to zagadnienie rzuciłyby systematycznie przeprowadzone studia nad metatekstowymi i metajęzykowymi wypowiedziami poety, na które nie ma tutaj jednak miejsca.

${ }^{36} \mathrm{Na}$ temat znaczenia przymiotnika fenomenologiczny w tym i innych kontekstach Norwidowskich zob. Sobotka 2004-2005: 182-183. 
Odpowiedzialność za tak pochodzące słowo wymaga troski o prawdę wszelkiego przekazu. Dąży więc on do tego, aby jego twórczość nie uchybiała wierności, dlatego przyznaje z jednej strony: „w dagueroty $\mathrm{p}$ [...] pióro zamieniam” (PW VI 177), a z drugiej: „Jam z tych poetów, co nie słówka nucę, / Ja to, co śpiewam, żyję i boleję...” (PW I 260). W pierwszej z tych wypowiedzi Norwid jawi się niemal reporterem, którego celem jest wierne odwzorowywanie rzeczywistości, w drugiej natomiast dodaje do tego obrazu, że między jego życiem a śpiewem nie ma sprzeczności.

W otwierającym Vade-mecum wstępie Do czytelnika poeta kreśli obowiązki poezji, postulując, aby „strona m o r a ln a, znaczne zajmowała [w niej - P.S.] miejsce" (PW II 9). Praktyczną realizacją tego postulatu są wiersze tego Norwidowego cyklu. Poeta rozwija w tym wstępie nowatorskie poglądy na nową poezję, sztukę i nowe społeczeństwo. Podejmuje dyskusje związane $\mathrm{z}$ dnową języka, które znajdują swoje reminiscencje w prowadzonej przez niego w tym czasie korespondencji (por. np. listy do Juliana Fontany, PW IX 206 nn., czy korespondencję z Ludwikiem Nabielakiem, m.in. PW IX 365). W licznych wierszach (por. Spowiedź, PW 128-129) zapowiada triumf Chrystusa i idei niesionej przez chrześcijaństwo oraz podkreśla konieczność pokładania nadziei w Bogu; taką wymowę ma między innymi zakończenie wiersza Śmierć, w którym poeta przekonuje, że tytułowa śmierć „Prócz chwili, w której wzięła - nic nie wzięła: / - Człek od niej starszy!” (PW II 116). Poeta wielokrotnie mówi także o konieczności moralnego doskonalenia, aby móc zbliżyć się do prawdy. Zapowiada wreszcie odnowę, jak w ostatniej zwrotce Fortepianu Szopena, jeśli ideał, który „,siegnął bruku”, odczytamy jako zapowiedź jego ,zmartwychwstania”37. Wszystkie te przykłady mogłyby realizować posłannictwo poety jako kapłana nadziei w świecie jej dni powszednich.

Jednakże - biorąc pod uwagę całą twórczość Norwida - wypowiedzi poety ujęte są w różne dysonanse. Raz przedstawia się on jako analityk sceny politycznej Europy ${ }^{38}$ i niestrudzony orędownik sprawy narodu (w różnych jego aspektach - religijnym, niepodległościowym itp.), nie oszczędzając rodakom nawet ocen gorzkich, ale i też pokazując drogi naprawy, gdzie indziej

37 Tę myśl niemal dosłownie przenoszę z tekstu, który napisałem wspólnie z Jadwigą Puzyniną (por. Puzynina, Sobotka: 2002: 19).

38 Jego polityczne i ekonomiczne prognozy były jednak przeważnie chybione. Opierały się w przeważającej mierze nie na ocenie rzeczywistości, lecz na uprawianej przez poetę historiozofii. 
z kolei kreuje się na poetę samotnego i nieszczęśliwego. Niektóre wypowiedzi Norwida można traktować jako elementy realizacji przez niego kapłaństwa nadziei, inne z kolei, zwłaszcza wyłącznie oceniające, o ironicznym zabarwieniu, piętnują wprawdzie ograniczoność narodową, lecz nie zawierają pierwiastka moralnego i Boskiego odniesienia. Wydaje się, że za kapłaństwem nadziei Norwida szczególnie przemawiają te z jego wystąpień, w których dochodzi do połączenia pierwiastków ogólnoludzkiego i chrześcijańskiego. Wymownym tego przykładem może być wiersz [Do Stanisławy Hornowskiej], w którym poeta sprzęga czas ewangeliczny z czasem ziemskim, wskazując na głębokie powiązania między współczesnym mu wiekiem dziewiętnastym a historią Zbawienia (por. Wojtyło 1987: 94-95), która wciąż się dzieje, co może być źródłem doświadczenia nadziei:
A Pani cóż ja powiem?... oto, że w tym życiu
Nic straconego nie ma na jawie, ni w skryciu,
$[\ldots]$
A co zginęło - myślisz - zakryte jest bramą
Lub cieniem jej, i z czasem będzie wyświecone!
I żadna łza, i żadna myśl, i chwila, i rok
Nie przeszły, nie przepadły [...].
I nie ma grobów... oprócz w sercu lub w sumieniu,
I nie ma krzyżów... oprócz na zimnym kamieniu,
Albowiem krzyż jest życie już wiek dziewiętnasty $[\ldots]$.

(PW I 266)

Ujęcie historii w jej wymiarze eschatologicznym i prawda o życiu wiecznym, które stało się możliwe dzięki zwycięstwu nad śmiercią na Golgocie, to w wierszu podstawowe elementy przesłania odsyłającego do nadziei. Życie jawi się jako celowe i konsekwentne podążanie ku dobru i każde cierpienie, każda chwila nabierają sensu w wymiarze wieczności, a nawet jeżeli teraz kładzie się na nich cień, to ostatecznie przecież się objawi, że jest ono świadectwem istnienia światła, ponieważ - jak pamiętamy - ,powiedziane nam było i nie zakryte, że światłość w ciemnościach świeci - a ciemności Jej nie ogarnęły!” (PW IX 53). Orędzie to głosi niewątpliwie poeta, którego można by z zastrzeżeniem nazwać kapłanem nadziei. Zdaniem Norwida nawet skrępowanie nieszczęścia całunem, jak to widzimy w innym wierszu, nie wyklucza zupełnie możliwości doświadczania nadziei (zob. PW I 9). 
Liczne Norwidowskie „skrzydlate słowa”, które dotyczą spraw uniwersalnych, a przy tym narodowych (nie ma tu sprzeczności, Norwid uczy bowiem, że aby być narodowym, trzeba być ponad-narodowym, por. PW III 569), moga przemawiać za realizacją przez poetę ideału kapłaństwa nadziei. Niewątpliwie do takich wypowiedzi należy zaliczyć te, w których nad treścią doraźną, ujętą w polityczne pęta, górę bierze Norwid moralista i wizjoner, przekonujący rodaków, że ojczyzna jest moralnym zjednoczeniem, a nie polem rywalizacji różnych partii, koczowiskiem polemik, które rodzą niezgodę i których rzeczywistościq jest dym wyrazów (!) (por. PW VII 8).

Norwidowski projekt odnowy języka religijnego również świadczy o pracach nad nadzieją narodu. Poeta był świadom własnej oryginalności językowej i podejmowanego przez niego na rzecz społeczeństwa wysiłku, „aby mowę chrześcijańską odtworzyć na nowo" (PW VI 413). Zdaniem ks. Dunajskiego, podobnie jak Dante dla języka włoskiego, tak Norwid dla polszczyzny był tlumaczem języka teologicznego (por. PW VI 412), czyli kapłanem nadziei ${ }^{39}$. Pisarstwo Norwida tak od strony treści, jak i formy wpisuje się w zjawiska o charakterze religijnym i społecznym. Świadomość widzenia przez poetę stanów rzeczy takimi, jakie są, jest według niego skorelowana z postępami na drodze dojrzałości chrześcijańskiej (por. PW VIII 180), to zaś znajduje odzwierciedlenie $w$ języku, jakim treści religijne są przekazywane ${ }^{40}$, a język ten - jak wskazuje na to Jadwiga Puzynina (2006: 40) - świadczy o wolności, świętości i całości słowa, w czym dostrzega ona ,akt wielkiej, obejmującej dzieje ludzkości metafizycznej NADZIEI".

Mimo tych tak licznych fragmentów, na podstawie których moglibyśmy myśleć o Norwidzie jako o swoistym kaptanie dni powszednich nadziei, poeta, którego dzieło zakorzenia się w chrześcijaństwie, który przy wszystkich czarnościach jego życia uczy nas, że „trzeba nadzieję mieć, ona jest cnotą..." (PW IV 329), nie jest jednak ani kapłanem, ani tym bardziej kapłanem nadziei; to po prostu utrudzony życiem człowiek, a zarazem poeta i myśliciel chrześcijański.

39 Myśl ta zawarta jest w pracy Dunajskiego (1996: 11-52). Autor pisze m.in., że Norwid „bardzo głęboko i oryginalnie ujmował samą istotę problemów [teologicznych - P.S.] i podstawowe dogmaty wiary" (ibidem, s. 32).

${ }^{40}$ Kwestii tu zawartych nie rozwijam, gdyż w moim pojęciu najlepiej odpowiada na nie książka Wojciecha Kudyby (2000). 


\begin{tabular}{|c|c|c|c|c|c|c|c|c|c|c|c|c|c|}
\hline \multicolumn{2}{|c|}{ KGZVY } & $\stackrel{\sim}{\sim}$ & & - & $N$ & $m$ & - & - & - & $N$ & - & - & $N$ \\
\hline \multicolumn{2}{|r|}{ 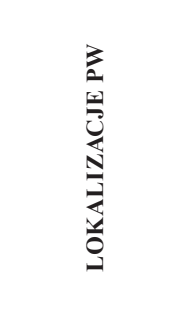 } & 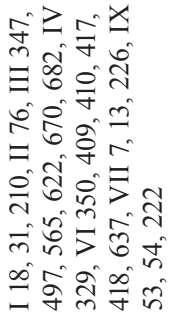 & & $\begin{array}{l}n \\
\Xi \\
\end{array}$ & $\begin{array}{l}\stackrel{8}{+} \\
\stackrel{+}{>}\end{array}$ & 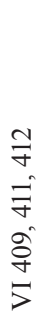 & 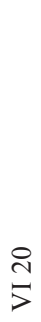 & $\begin{array}{l}\stackrel{\mathscr{\vartheta}}{\mathcal{F}} \\
\stackrel{7}{F}\end{array}$ & $\stackrel{\text { 志 }}{\stackrel{\Xi}{\Xi}}$ & $\begin{array}{l}\infty \\
\forall \\
\text { वे } \\
\stackrel{8}{+} \\
>\end{array}$ & $\begin{array}{l}n \\
\text { o } \\
j \\
j\end{array}$ & $\begin{array}{l}\infty \\
\infty \\
\infty \\
\Xi \\
\equiv\end{array}$ & $\begin{array}{l}\bar{ָ} \\
\infty \\
\stackrel{N}{N} \\
>\end{array}$ \\
\hline \multirow{2}{*}{$\begin{array}{l}\infty \\
\infty \\
\infty \\
1 \\
\\
\infty\end{array}$} & vZOyd & & & & & & & & & & & & \\
\hline & VfZGOd & & & & & & & & & & & & \\
\hline \multirow{2}{*}{$\begin{array}{l}\stackrel{0}{0} \\
\infty \\
T \\
\mathbb{\infty} \\
\infty \\
0\end{array}$} & VZOYd & & & & & & & & & & & & \\
\hline & vгZজOd & & & & & & & & & & & & $N$ \\
\hline \multirow{2}{*}{$\begin{array}{l}\stackrel{8}{0} \\
\infty \\
+ \\
\infty \\
\infty\end{array}$} & vZOyd & $=$ & & & $N$ & $m$ & & - & & $\sim$ & - & - & \\
\hline & vfZGOd & $n$ & & & & & & & & & & & \\
\hline \multirow{2}{*}{$\begin{array}{l} \pm \\
\infty \\
\infty \\
1 \\
\tilde{N} \\
\infty \\
\infty\end{array}$} & vZOyd & - & & & & & & & & & & & \\
\hline & vfZ畐Od & & & & & & & & & & & & \\
\hline \multirow{2}{*}{ 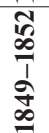 } & VZOUd & & & & & & & & & & & & \\
\hline & vrZ录Od & $N$ & & & & & & & & & & & \\
\hline \multirow{4}{*}{ 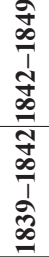 } & VZOYd & N & & - & & & & & & & & & \\
\hline & VrZGOd & - & & & & & & & - & & & & \\
\hline & vZOyd & & & & & & - & & & & & & \\
\hline & vfZGOd & $N$ & & & & & & & & & & & \\
\hline & & $\begin{array}{l}\frac{\pi}{\mathbb{N}} \\
\frac{\mathbb{N}}{\mathbb{J}} \\
\frac{\pi}{=}\end{array}$ & 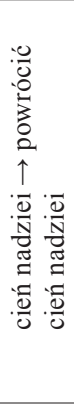 & 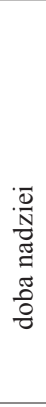 & 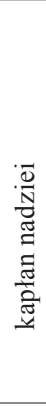 & 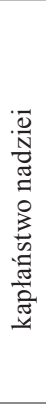 & 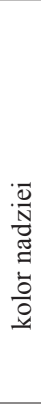 & 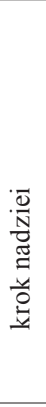 & 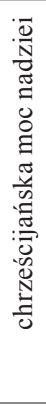 & 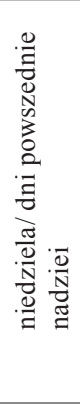 & 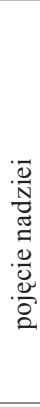 & 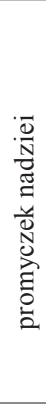 & 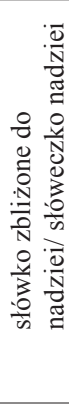 \\
\hline & 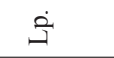 & - & & $N$ & $m$ & 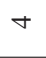 & in & 6 & $r$ & $\infty$ & $a$ & $ㅇ$ & $=$ \\
\hline
\end{tabular}




\begin{tabular}{|c|c|c|c|c|c|c|c|c|c|c|c|c|c|c|c|c|}
\hline & NGZVY & - & - & in & $m$ & $n$ & - & - & $\sim$ & - & - & $\mathrm{N}$ & - & - & - & $\infty$ \\
\hline & 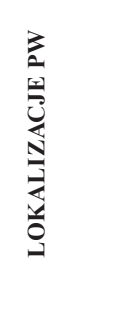 & $\begin{array}{l}\stackrel{\infty}{\sim} \\
\Xi \\
\Xi\end{array}$ & $\begin{array}{l}\underset{\Delta}{\Delta} \\
\Xi \\
\Xi\end{array}$ & 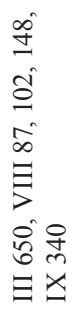 & 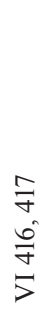 & 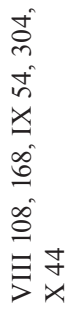 & $\begin{array}{l}\stackrel{2}{\Xi} \\
\Rightarrow\end{array}$ & $\begin{array}{l}\stackrel{n}{\sim} \\
\stackrel{\Xi}{\Xi}\end{array}$ & $\begin{array}{l}\stackrel{+}{+} \\
\stackrel{\vec{m}}{\Xi} \\
\Xi\end{array}$ & $\begin{array}{l}\stackrel{a}{\alpha} \\
\qquad\end{array}$ & $\begin{array}{l}\sigma \\
\Xi \\
\Xi\end{array}$ & 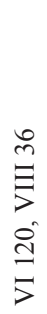 & $\frac{\stackrel{ }{J}}{J}$ & $\begin{array}{l}\stackrel{2}{\text { m }} \\
\underset{x}{2}\end{array}$ & $\begin{array}{l}\stackrel{0}{=} \\
\underline{x}\end{array}$ & 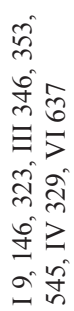 \\
\hline $\begin{array}{l}\infty \\
\infty \\
\infty\end{array}$ & vZO\&d & & & & & & & & & & & - & - & & & \\
\hline 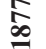 & vfZGOd & & & & & & & & & & & & & & & \\
\hline$\stackrel{0}{\infty}$ & VZOYd & & & & & - & & & & - & & & & & & \\
\hline 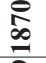 & VPZGOd & & & & & & & & & & & & & & & \\
\hline $\begin{array}{l}\hat{b} \\
\infty\end{array}$ & vZOYd & & & - & $m$ & N & & & & & & & & - & - & - \\
\hline $\begin{array}{l}\dot{1} \\
\infty\end{array}$ & VfZGOd & & & & & & & & & & & & & & & $m$ \\
\hline $\begin{array}{l}\overrightarrow{0} \\
\infty\end{array}$ & VZOYd & - & - & & & & & - & & & & & & & & \\
\hline $\begin{array}{l}\tilde{\infty} \\
\infty\end{array}$ & vfZGOd & & & & & & & & & & & & & & & \\
\hline $\mathscr{\infty}$ & VZOYd & & & $m$ & & N & - & & & & & & & & & \\
\hline$\underset{+}{\infty}$ & VfZGOd & & & & & & & & & & & & & & & - \\
\hline$\underset{+}{\infty}$ & VZO\&d & & & & & & & & $N$ & & - & - & & & & \\
\hline$\underset{0}{2}$ & VPZGOd & & & - & & & & & & & & & & & & $N$ \\
\hline$\underset{\infty}{\mathcal{Y}}$ & VZO\&d & & & & & & & & & & & & & & & \\
\hline હે & vIZGOd & & & & & & & & & & & & & & & - \\
\hline & & 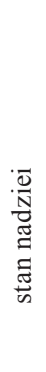 & 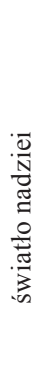 & 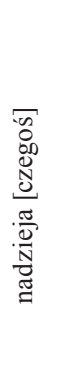 & 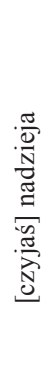 & 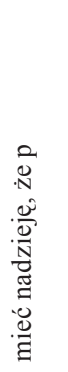 & 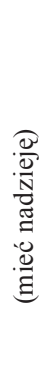 & 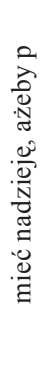 & 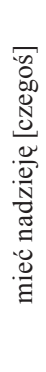 & 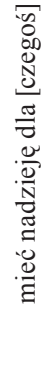 & 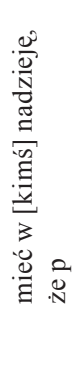 & 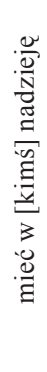 & 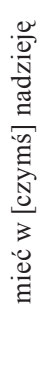 & 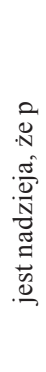 & 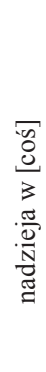 & 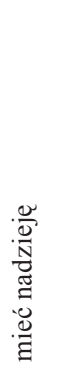 \\
\hline & $\dot{1}$ & 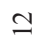 & 9 & \pm & $\cong$ & $\stackrel{0}{-}$ & I & $\stackrel{\infty}{-1}$ & 2 & 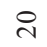 & $\vec{\sim}$ & ปี & $\tilde{\lambda}$ & $\stackrel{\sim}{\sim}$ & 2 & i \\
\hline
\end{tabular}




\begin{tabular}{|c|c|c|c|c|c|c|c|c|c|c|c|c|c|c|c|c|c|}
\hline \multicolumn{2}{|c|}{ WGZVY } & - & 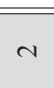 & - & $\sim$ & & - & - & - & - & $m$ & - & - & - & - & - & - \\
\hline & 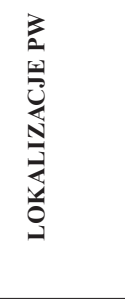 & $\frac{\tilde{n}}{x}$ & $\begin{array}{l}\cong \\
\Xi \\
\Xi \\
\ddot{D} \\
\stackrel{N}{ } \\
己\end{array}$ & 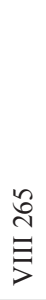 & $\stackrel{\Xi}{\vec{\exists}}$ & 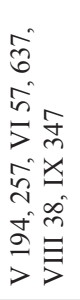 & $\begin{array}{l}\stackrel{尺}{6} \\
\Xi\end{array}$ & $\begin{array}{l}\infty \\
\infty \\
\stackrel{n}{\Xi}\end{array}$ & $\frac{\sim}{\geq}$ & 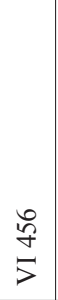 & 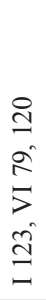 & 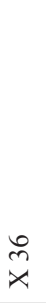 & $\begin{array}{l}\stackrel{\sim}{n} \\
\Xi\end{array}$ & $\begin{array}{l}\hat{\delta} \\
\Xi \\
\Xi\end{array}$ & $\underset{\Xi}{\stackrel{\overbrace{}}{\Xi}}$ & 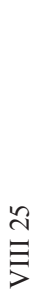 & $\begin{array}{l}\hat{\widehat{\sigma}} \\
\Xi \\
\Xi\end{array}$ \\
\hline \multirow{4}{*}{$\begin{array}{l}\infty \\
\infty \\
\infty \\
1 \\
1 \\
\infty \\
\infty \\
0 \\
0 \\
\infty \\
1 \\
1 \\
\infty \\
\infty \\
0\end{array}$} & vZOyd & & & & & & & & & & $\sim$ & & & & & & \\
\hline & vfZяод & & & & & & & & & & & & & & & & \\
\hline & vZOyd & & & & & & & & & & & - & & & & & \\
\hline & vfZGOd & & & & & N & & & & & & & & & & & \\
\hline \multirow{2}{*}{ 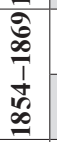 } & vZOyd & - & & - & $\sim$ & $m$ & & & & - & & & & & & & \\
\hline & VгZЯОd & & - & & & & - & - & & & & & & - & & & - \\
\hline \multirow{2}{*}{ 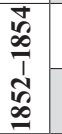 } & vZOyd & & & & & & & & & & & & & & & & \\
\hline & vfZGOd & & & & & & & & & & & & & & & & \\
\hline \multirow{2}{*}{ 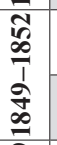 } & vZOyd & & & & & & & & & & & & & & & & \\
\hline & VPZGOd & & & & & & & & & & - & & - & & & & \\
\hline \multirow{4}{*}{ 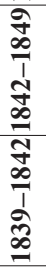 } & vZOyd & & - & & & - & & & & & & & & & - & - & \\
\hline & vfZłOd & & & & & & & & & & & & & & & & \\
\hline & vZOyd & & & & & & & & & & & & & & & & \\
\hline & VPZЭOd & & & & & & & & - & & & & & & & & \\
\hline & & 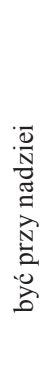 & 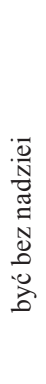 & 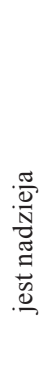 & 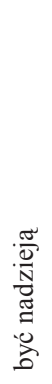 & 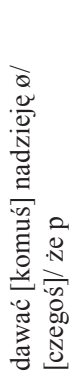 & 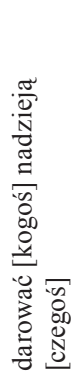 & 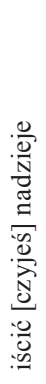 & 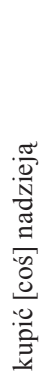 & 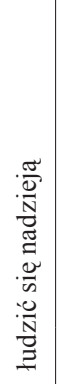 & 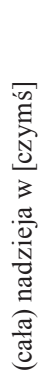 & 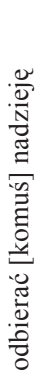 & 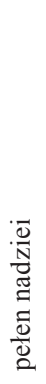 & 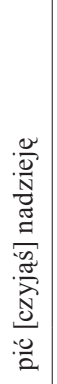 & 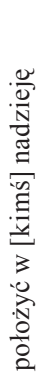 & 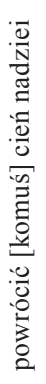 & 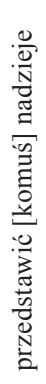 \\
\hline & $\dot{3}$ & $\hat{\sim}$ & $\stackrel{\infty}{\sim}$ & নे & 尺े & $\bar{m}$ & $\approx$ & m & mे & $n$ & i & $\hat{n}$ & $\infty$ & ले & 우 & $F$ & F \\
\hline
\end{tabular}




\begin{tabular}{|c|c|c|c|c|c|c|c|c|c|c|c|c|c|c|c|c|c|c|}
\hline \multicolumn{2}{|c|}{ WAZVY } & - & - & - & N & $m$ & - & $m$ & - & - & $n$ & - & - & - & \multicolumn{4}{|l|}{ 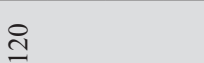 } \\
\hline & 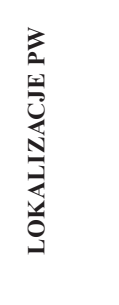 & $\begin{array}{l}\stackrel{\text { ป }}{\Xi} \\
\stackrel{\Xi}{>}\end{array}$ & $\frac{\stackrel{7}{7}}{\stackrel{5}{5}}$ & $\underset{x}{\stackrel{\forall}{x}}$ & 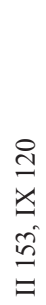 & 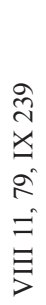 & $\begin{array}{l}\stackrel{\text { N }}{n} \\
\stackrel{5}{>}\end{array}$ & 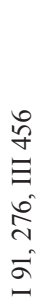 & $\begin{array}{l}\overline{\text { m }} \\
\text { ヨ }\end{array}$ & $\beth$ & 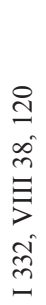 & $\begin{array}{l}\stackrel{8}{\Xi} \\
\Xi\end{array}$ & $\stackrel{\underset{\exists}{\Xi}}{\Xi}$ & $\begin{array}{l}\stackrel{\infty}{\varrho} \\
\equiv\end{array}$ & & & & \\
\hline \multirow{4}{*}{\begin{tabular}{|c|}
0 \\
0 \\
0 \\
1 \\
1 \\
0 \\
0 \\
0 \\
0 \\
0 \\
1 \\
10 \\
0 \\
0 \\
\end{tabular}} & vZOyd & & & & & & & & & & & & & & t & \multirow{2}{*}{$\nabla$} & \multirow{14}{*}{ P } & \multirow{14}{*}{$\varnothing$} \\
\hline & vгZяОд & & & & & & & & & & & & & & 0 & & & \\
\hline & vZOyd & & & - & & & - & & & & & & & & $n$ & \multirow{2}{*}{$a$} & & \\
\hline & VPZGOd & & & & & & & & & & & & & & $\nabla$ & & & \\
\hline$\hat{\varnothing}$ & vZOyd & & - & & - & - & & & & & & & & & 尹 & \multirow{4}{*}{ in } & & \\
\hline 要 & VFZGOd & & & & - & & & - & & & - & - & & & I & & & \\
\hline \multirow{2}{*}{ 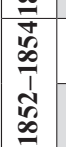 } & vZOyd & - & & & & & & & & & & & & & $n$ & & & \\
\hline & VГZЭОd & & & & & & & & & & & & & & 0 & & & \\
\hline$\tilde{\infty}$ & vZOyd & & & & & - & & & & & $N$ & & & - & 은 & \multirow{2}{*}{$\simeq$} & & \\
\hline$\underset{0}{\infty}$ & VPZGOd & & & & & & & - & & & & & - & & $r$ & & & \\
\hline \multirow{4}{*}{ 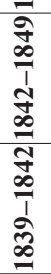 } & vZO\&d & & & & & - & & & & & N & & & & \pm & \multirow{2}{*}{$\vec{\sim}$} & & \\
\hline & VPZGOd & & & & & & & - & - & & & & & & $r$ & & & \\
\hline & vZO\&d & & & & & & & & & & & & & & - & \multirow{2}{*}{6} & & \\
\hline & VPZGOd & & & & & & & & & - & & & & & $n$ & & & \\
\hline & & 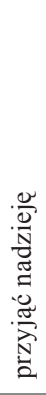 & 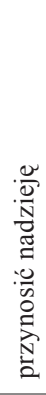 & 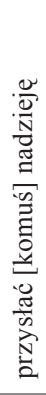 & 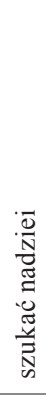 & 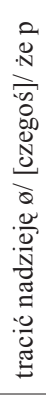 & 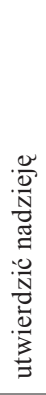 & 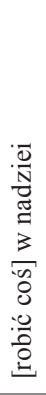 & 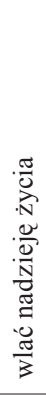 & 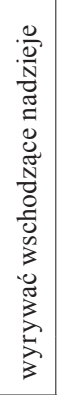 & 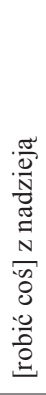 & 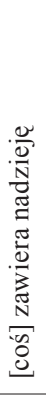 & 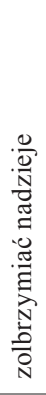 & 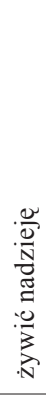 & \multirow{2}{*}{ 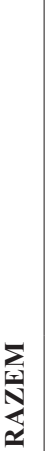 } & \multirow[t]{2}{*}{$\sum_{\infty}^{\mathbb{S}}$} & \multirow[t]{2}{*}{ 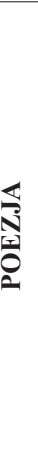 } & \multirow[t]{2}{*}{$\begin{array}{l}\overleftrightarrow{N} \\
0 \\
\text { Oñ }\end{array}$} \\
\hline & $\dot{1}$ & $\mathscr{\gamma}$ & $\stackrel{f}{f}$ & $\wp$ & \& & f & $\stackrel{\infty}{+}$ & gे & 오 & $\bar{n}$ & กี & $n$ & $\stackrel{4}{n}$ & $n$ & & & & \\
\hline
\end{tabular}




\section{Bibliografia}

Chlebowski P., 2000, Cypriana Norwida „Rzecz o wolności słowa”. Ku epopei chrześcijańskiej, Lublin: Towarzystwo Naukowe Katolickiego Uniwersytetu Lubelskiego.

Congar Y. M. J., 1953, Jalons pour une théologie du ladïcat, Paris: Les Éditions du Cerf.

Dunajski A., 1996, Teologiczne czytanie Norwida, Pelplin: „Bernardinum”.

Forstner D., OSB, 1990, Świat symboliki chrześcijańskiej, przekład i oprac. W. Zakrzewska, P. Pachciarek, R. Turzyński, Warszawa: Instytut Wydawniczy PAX.

Frege G., 1977, Pisma semantyczne, tłum. B. Wolniewicz, Warszawa: Wydawnictwo Naukowe PWN.

Górski K., Hrabec S. (red.), 1967, Słownikjęzyka Adama Mickiewicza, t. 5, Wrocław-Warszawa-Kraków: Ossolineum.

Halkiewicz-Sojak G., 1998, Wobec tajemnicy prawdy. O Norwidowskich obrazach „całości”, Toruń: Wydawnictwo UMK.

Kadyjewska A., Korpysz T., Puzynina J., 2000, Chrześcijaństwo w pismach Cypriana Norwida, Warszawa: Uniwersytet Warszawski. Wydział Polonistyki. Pracownia Słownika Języka C. Norwida.

Kudyba W., 2000, „Aby mowę chrześcijańska odtworzyć na nowo...”. Norwida mówienie o Bogu, Lublin: Towarzystwo Naukowe Katolickiego Uniwersytetu Lubelskiego.

Leibniz G. W., 1975, Tabulae definitiorum, tłum. M. Kamińska, A. Werpachowska, w: E. Janus (red.), Słownik i semantyka. Definicje semantyczne, Wrocław: Zakład Narodowy im. Ossolińskich - Wydawnictwo PAN, s. 8-90.

Norwid C., 1966, Dzieła zebrane, t. 2: Wiersze. Dodatek krytyczny, opracował J. W. Gomulicki, Warszawa: Państwowy Instytut Wydawniczy.

Norwid C., 1971-1976, Pisma wszystkie, zebrał, tekst ustalił, wstępem i uwagami krytycznymi opatrzył Juliusz W. Gomulicki, t. 1-11, Warszawa: Państwowy Instytut Wydawniczy.

Novum Testamentum Graece et Latine, 1997, red. Eb. Nestle, Er. Nestle, B. Aland, K. Aland, J. Karawidopoulos, C. M. Martini, B. M. Metzger, Stuttgart: Deutsche Bibelgesellschaft.

Pieper J., 2000, O miłości, nadziei i wierze, przeł. I. Gano i K. Michalski, Poznań: W drodze.

Puzynina J., 1993, Wstęp, w: Słownictwo etyczne Cypriana Norwida. Część 1: prawda, fałsz, kłamstwo, red. J. Puzynina, Warszawa: Uniwersytet Warszawski. 
Puzynina J., 2006, Stowo poety, Warszawa: Wydawnictwa Uniwersytetu Warszawskiego.

Puzynina J., Soвotкa P., 2002, Norwid-prorok?, w: Norwid-nasz współczesny. Profecja i recepcja, red. naukowa C. P. Dutka, Zielona Góra: Pro Libris, s. 13-21.

Ritter J. (red.), 1974, Historisches Wörterbuch der Philosophie, t. 3, Stuttgart-Basel: Schabe.

RykaczewsKi E., 1873, Słownik języka polskiego podtug Lindego i innych nowszych źródet, wyd. II, Berlin: B. Behr.

SAwicka-Leszczuk B., 2003, „Kło ze źródła pije...”. Wokół Norwidowskiej koncepcji poety, w: Czytajac Norwida 2, red. S. Rzepczyński, Słupsk: Wydawnictwo PAP.

SJPLin.: Linde S. B., 1809, Słownik języka polskiego, t. 2, cz. I, Warszawa: U Autora.

Sовотка P., 2004-2005, Fenomenologia, personalizm, frazeologia, gramatyka, Studia Norwidiana 22-23, s. 181-187.

Soвотка P., 2006, Semantyka nadziei i jej aspekty pragmatyczne w języku polskim. Studium relacji między pojęciem doksastycznym i rzeczywistościq, Warszawa (maszynopis).

Soвотка P., 2007, Staro- i nowotestamentowe źródła judeochrześcijańskiego pojęcia nadziei - preliminaria, Prace Filologiczne LIII, s. 543-555.

Stala M., 1998, (nie)przynoszonej przez poetów, Tygodnik Powszechny, nr 3 (21), 12 IV 1998.

Teleżyńska E., 1994, Nazwy barw w twórczości Cypriana Norwida, Warszawa: Uniwersytet Warszawski. Wydział Polonistyki. Pracownia Słownika Języka C. Norwida.

Thomae de Aquino, 1929, Summa theologiae, Éditions de la Revue des Jeunes, Paris, II-II q. 17 a. 6.

Tischner J., 1994, Świat ludzkiej nadziei, Kraków: Wydawnictwo Znak.

Toruń W., 2003, Wokół Norwidowskiej koncepcji słowa, Lublin: Towarzystwo Naukowe Katolickiego Uniwersytetu Lubelskiego.

Wittgenstein L., 1997, Philosophical Investigations, London: Blackwell.

WojtyŁo E., 1987, „Msza wieczna świata” w historiozoficznych lirykach Cypriana Norwida, Acta Universitatis Wratislaviensis No 985. Prace Literackie XXVII, Wrocław, s. 85-97.

\section{Norwid's concept of hope}

( s u m m a r y)

The present paper is concerned with the lexical item nadzieja 'hope' in the works of Cyprian Norwid, especially its semantics and pragmatics. It discusses the means 
of expressing the concept of hope in both Norwid's prose and poetry, and the collocations of the word nadzieja in his idiolect. Additionally, it describes Norwid's specific understanding of hope, its role in human life and its place in religious attitudes of people. The concept of hope in Norwid's works is both an epistemic and axiological one, especially when the poet is concerned with hope as a theological virtue (besides faith and love). In both these senses hope means that somebody does not know whether something has happened, is happening, or will happen. Hope understood in such a way refers to the future, however not to a future event, but to some future good, which is in effect some desired phenomenon, and ultimately human salvation. 